\title{
Investigation in forensic nursing: trajectories and possibilities of action
}

\author{
A perícia na enfermagem forense: trajetórias e possibilidades de atuação \\ La pericia en la enfermería forense: trayectorias y posibilidades de actuación
}

How to cite this article:

Furtado BMASM, Fernandes CLEA, Silva JOM, Silva FP, Esteves RB. Investigation in forensic nursing: trajectories and possibilities of action. Rev Esc Enferm USP. 2021;55:e20200586. DOI: http://dx.doi.org/10.1590/1980-220X-REEUSP-2020-0586.

\section{Betise Mery Alencar Sousa Macau Furtado $^{1}$}

\section{(D) Carmela Lília Espósito de Alencar} Fernandes $^{2}$

\section{(D) Juliana de Oliveira Musse Silva ${ }^{3}$ \\ Felicialle Pereira da Silva ${ }^{4}$ \\ Rafael Braga Esteves ${ }^{5}$}

${ }^{1}$ Universidade de Pernambuco, Faculdade de Enfermagem Nossa Senhora das Graças, Programa de Mestrado em Perícias Forenses da Faculdade de Odontologia, Recife, PE, Brazil.

${ }^{2}$ Hospital Militar de Área de Recife, Exército Brasileiro, Recife, PE, Brazil.

${ }^{3}$ Hospital Universitário da Universidade Federal de Sergipe, Aracaju, SE, Brazil.

${ }^{4}$ Universidade de Pernambuco, Faculdade de Enfermagem Nossa Senhora das Graças, Recife, PE, Brazil.

${ }^{5}$ Universidade de São Paulo, Escola de Enfermagem de Ribeirão Preto, Ribeirão Preto, SP, Brazil.

\begin{abstract}
To theorize and reflect on the possibilities of the forensic nurse's performance, emphasizing the work as a civil and criminal expert, based on the Brazilian legislation, ethical principles, and comprehensive care for human beings. This is a theoretical study of exploratory nature with reflective and critical characteristics. It was based on the history of the national and international development of the forensic nursing specialty. It is organized into four categories, namely: areas of practice of forensic nurses in North American countries; state-of-the-art North American forensic nursing and the Brazilian reality, and nursing action in the face of violence. This way, international history, national panorama, and in-depth theoretical study were concatenated. Evidence of the contribution of forensic nursing to criminal and civil areas points to the emerging need for implementation and recognition of this practice within the scope of forensic investigation in Brazil with the inclusion of the topic in undergraduate courses.
\end{abstract}

\section{DESCRIPTORS}

Forensic Nursing; Expert Testimony; Exposure to Violence; Advanced Practice Nursing; Justice Administration System. 


\section{INTRODUCTION}

Forensic nursing emerges with the application of the nursing science based on the perspective of health and justice systems overlap. The history of this specialty dates back to the 1970s in the United States of America (USA), when a group of women's rights activist nurses demanded comprehensive care for victims of rape, including medical evidence in this process. At that time, the exams performed by the nurses included the physical examination and the collection of forensic evidence during the care provided to victims of sexual violence. These professionals were not recognized for their work as forensic experts, and were not able to provide clarifications to the judicial authority in the courts (1). $^{(1)}$

The implementation of the program Sexual Assault Medical Forensic Exam in the USA in the 1980s brought greater evidence to the nurse's attributions as an examiner, becoming a new field of specialization ${ }^{(2)}$. To provide care to patients, victims of sexual violence, in addition to the technical and scientific knowledge of traditional nursing practice, the development of new skills, abilities, and responsibilities transversal to the areas of law and expertise were required. The examining nurse, besides classifying and describing the physical injuries, was responsible for acting as a forensic expert, collecting forensic evidence before the analysis and interpretation of the scientific police, such as semen, saliva and blood collection, for further analysis by forensic criminal laboratories ${ }^{(2)}$.

At the beginning of the nursing work in the care of victims of sexual violence in the USA, there was resistance as to the legitimacy of carrying out forensic examinations on victims assisted by these professionals. This resistance began to diminish with the incorporation of these professionals as collaborators for justice. In addition to the immediate health care provided to victims, knowledge of forensics and criminal justice legislation was included in the patients' history taking and physical examination. This role was strengthened in the 1980s and 1990s, when nurses became important subjects in the collection of forensic clues and evidence ${ }^{(3)}$.

To meet this new demand of work with victims of violence in the provision of care by nurses, the inclusion of new skills and certified qualification for the work of these professionals in the forensic area was required. Nurses acted as independent examiners in the multidisciplinary team that included, in addition to health professionals, police officers, prosecutors, and public defenders. This model was first developed in California, USA, with the Sexual Assault Nurse Examiner and Sexual Assault Response Teams ${ }^{(4)}$.

Another step towards the consolidation of forensic nursing practices concerns the foundation of the International Association of Forensic Nurses (IAFN), in 1992, which contributed to the recognition of the Forensic Nursing specialty. Virginia Lynch, IAFN's first president, nurse death investigator, considered one of the precursors of forensic nursing, and member of the American Academy of Forensic Sciences, contributed to the recognition of forensic nursing as a discipline, which gained status of science ${ }^{(5)}$.
Thus, based on their training and journey in this field of work, it can be observed that nurses have holistic training to work in the scenario of patient care in the field of forensic science.

Most emergency staff and pre-hospital care providers are not trained in forensics; thus, the motivated and qualified nurse can serve as an invaluable resource for the criminal justice system, for the hospital, and for the patient ${ }^{(6)}$.

Therefore, this manuscript was prepared with the aim of reflecting on the possibilities of the nurse working as a civil and criminal expert, revisiting concepts and trajectories relevant to the science of forensic nursing, based on the Brazilian legislation, ethical principles, and comprehensiveness of care to the human being.

\section{METHOD}

Theoretical production of reflection, supported by the framework of published literature on the areas of forensic science and nursing. It correlates the state-of-the-art nursing work in the forensic area inserted into categories, for consideration and discussion on the trajectories and possibilities of nursing performance in this scenario.

\section{Forensic Nurses Areas of Work IN North American Countries}

In countries such as the United States and Canada, forensic nurses can work in different subspecialties ${ }^{(7)}$, such as those described in Chart 1.

In addition to the subspecialties described in Chart 1, there are also the Legal Nurse Consultant (LNC) and the Nurse Coroner (NC), which may or may not be exercised by forensic nurses. The LNCs are nurses and also lawyers who provide consultancy to other health professionals, in situations in which care practices generate legal, civil, and criminal consequences, such as in cases of neglect and malpractice, for example. The NC is the nurse who needs to take a specific course to be a coroner; this professional is authorized by the State to determine the cause of death, collaborate in the identification of victims, and notification to family members. They can also carry out certification on questionable deaths ${ }^{(8)}$.

North American forensic nursing has a consolidated trajectory; however, the challenge of establishing the coherence of care centered on the patient's health and well-being and carrying out the collection of forensic evidence is still present. Objectivity and impartiality are required on the part of the professional, as well as the knowledge about laws and emotional balance to participate as a witness in court in required cases ${ }^{(9)}$.

\section{Forensic Nursing and the Brazilian Reality}

In Brazil, the first scientific discussions addressing the specialty came in 2009 with the article "Enfermagem Forense: uma especialidade a conhecer" (Forensic Nursing: a specialty to be known), the result of the work of two Brazilian nurses, Karen Beatriz Silva and Rita de Cássia Silva. The aim of the article was to report the role of the forensic nurse in the 
Chart 1 - Areas in which the forensic nurse can work in different subspecialties in the United States and Canada - Aracaju, SE, Brazil, 2021.

\begin{tabular}{|l|l|}
\hline Forensic nursing subspecialties & Work \\
\hline Clinical Forensic Nurse (CFN) & $\begin{array}{l}\text { Forensic nurse in charge of assisting victims of violence who are attended in a hospital environment. In } \\
\text { charge of documenting all information related to violence and preservation of evidence. }\end{array}$ \\
\hline Forensic Nurse Investigator (FNI) & $\begin{array}{l}\text { Forensic nurse who works under the jurisdiction of a medical-legal office. Works with the investigation } \\
\text { of circumstances related to the violent act, from the circumstances of death to insurance fraud. }\end{array}$ \\
\hline Forensic Nurse Examiner (FNE) & $\begin{array}{l}\text { Forensic nurse who can work in several subspecialties to identify cases of interpersonal violence, } \\
\text { especially through physical examination. }\end{array}$ \\
\hline Sexual Assault Nurse Examiner (SANE) & $\begin{array}{l}\text { Forensic nurse trained to act in cases of sexual violence, performing the embracement, psychological } \\
\text { support, physical examination, and collection of evidence. }\end{array}$ \\
\hline Forensic Psychiatric Nurse (FPN) & Forensic nurse specialized in the care of offenders with psychiatric disorders and in custody. \\
\hline
\end{tabular}

Source: FERREIRA (2018).

USA and their different areas of work: hospitals, courts of law, community and health services ethics committees; in addition, in educational activities for individuals or groups with risk behaviors, such as alcohol and other drug abuse, and especially in the prevention of various forms of violence. According to the authors, the holistic basis of nursing favors the development of bonds with victims and establishes trusting relationships, facilitating cooperation with the forensic examination $^{(10)}$.

In 2011, forensic nursing was recognized as a specialty, but it was only in 2017 that the areas of expertise were regulated $^{(11)}$. According to the Resolution by the Federal Nursing Council (Cofen), the Forensic Nurse is:

[...] A bachelor of nursing, holder of a graduate certificate or a Master's degree in forensic nursing issued by a Higher Education Institution (IES) recognized by the Ministry of Education and Culture $(M E C)$, or granted by Societies, Associations, or Colleges of Specialists, registered under the Cofen System/Regional Councils, in accordance with Cofen Resolution No. 389/2011 [...]. (COFEN, 2017, art.1).

In Brazil, the forensic nurse can work in 8 (eight) different areas $^{(11)}$, as described in Chart 2.

Forensic nurses' areas of activity in Brazil, according to the COFEN Resolution, aim to: reach victims of sexual violence, maltreatment, trauma, and other forms of violence; respond to humanitarian emergencies; provide assistance to the prison population; work in psychiatry and investigation, technical assistance and consultancy; act in the preservation of evidence, and postmortem ${ }^{(11)}$.

Among the general competencies of the Brazilian forensic nurse are the recognition and embracement of victims of violence, as well as the elaboration of individualized care plans. In addition to these, the document also mentions the possibility of the professional working on the activities of a judicial expert, in accordance with the provisions of Articles 156 et seq. of Law No. 13.105/2015 (Civil Procedure Code) and Articles 275 et seq. of Executive Law No. 3.689/1941 (Criminal Procedure Code); providing expert testimony in court, in active participation with the judicial system; and acting as a technical assistant in cases involving issues related to nursing ${ }^{(11-13)}$.
Chart 2 - Areas in which the forensic nurse can work in Brazil Aracaju, SE, Brazil, 2021.

\begin{tabular}{|l|l|}
\hline Area No. & \multicolumn{1}{|c|}{ Areas of work } \\
\hline Area 1 & Sexual violence \\
\hline Area 2 & Prison system \\
\hline Area 3 & Psychiatry \\
\hline Area 4 & $\begin{array}{l}\text { Forensic Investigation, Technical Assistance, and } \\
\text { Consultancy }\end{array}$ \\
\hline Area 5 & Evidence collection and preservation \\
\hline Area 6 & Postmortem \\
\hline Area 7 & Mass Disaster, Humanitarian Missions, and catastrophes \\
\hline Area 8 & $\begin{array}{l}\text { Maltreatment, trauma, and other forms of violence in the } \\
\text { different cycles of life }\end{array}$ \\
\hline
\end{tabular}

Source: COFEN (2017).

Regarding the specific skills of this professional, they are: the preservation of forensic evidence and of the chain of custody; collection of pertinent information through photos and written documentation; the preparation of reports and opinions for the performance of the Judiciary Power; and the provision of consultancy in cases of litigation related to the forensic area in the context of health care, civil liability for bodily injuries, fraud, and other abuses ${ }^{(14)}$.

Forensic nurses, in their training, learn specific techniques and acquire knowledge to provide assistance in situations of violence and, therefore, they are considered investigators with expertise in this area. Glimpsing the role of nurses in the investigation area encompasses two possibilities: the civil and criminal spheres. In the area of civil investigation, this professional can work in the audit of medical accounts, administration in health services, as well as in situations involving the investigation of malpractice, recklessness, neglect in nursing care, such as in cases of adverse events, which may occur during the care provided to patients ${ }^{(15)}$.

In the criminal sphere, although the regulation by the professional council covers the Institutes of Forensic Medicine as the field of action of the forensic nurse, to work in these places the professional has to be an official expert, a position achieved through a public examination ${ }^{(15)}$. 
Despite the competences and contributions of forensic nursing to health and public safety, state and/or national laws for the creation of the position of forensic nurse expert have not yet been regulated. However, this professional can take public examinations to be a criminal expert if he/she holds an undergraduate degree within the general area ${ }^{(11)}$. Only the state of Paraná specified in a public notice the nursing area for the criminal expert examination ${ }^{(16)}$.

The criminal expert, or also called official expert, is supported by Law 12.030/09, which defines as criminal experts coroners and dentists with specific undergraduate degree detailed in regulation, according to the need of each agency and by area of professional performance ${ }^{(16)}$. In addition, considering the Brazilian Criminal Procedure Code, Executive Law no. 3.689 of October 3, 1941 (Código de Processo Penal brasileiro, Decreto de Lei no 3.689 de 03 de Outubro de 1941)(17), the corpus delicti examination and other investigations shall be carried out preferably by official experts, holders of an undergraduate degree; however, in the absence of an official expert, the exam may be performed by two reputable persons, with an undergraduate degree, preferably in the specific area. Therefore, the forensic nurse may be summoned by the courts to clarify technical and scientific questions about a process in the role of a judicial expert, or also called ad hoc experts.

In this context, for the consolidation of the role of specialist nurses in the field of investigation in Brazil, the coordination with the legislative power is required for the creation of laws establishing the position of forensic nurses as criminal experts. Massive dissemination of the importance of the specialty for society and public management is emergent, as well as the inclusion of specific subjects in the curriculum of undergraduate courses and the expansion of graduate courses that include theoretical and practical classes.

\section{Investigation as Part of the Nurse's Work Process}

The physical examination is part of the nurse's daily work routine. He/she thoroughly assesses the symptoms and signs presented by the patient, allowing, from this collected information, the development of the nursing care plan according to the needs and problems observed, that is, preparing the Nursing Care Systematization. For that, he/she follows propaedeutic techniques aiming at a complete evaluation of the several singularities inherent to the human being ${ }^{(18)}$.

Within this model, forensic nursing emerges as a possibility to improve and expand this investigative power, under the forensic perspective, whose focus is the patient, either victim or aggressor, alive or dead. The area of investigation emerges as a sub-area of action for forensic nurses in response to demands for assistance in situations of violence and need for dialogue between health and justice; he/she can also provide consultancy, audit, and give opinions on nursing matters, checking whether there is damage resulting from incompetence, recklessness, or neglect from the nursing team in the provision of care $^{(19)}$.

In a study carried out in India, almost two decades ago, the concern with the introduction of nurses in the care of victims of violence was already observed, within the context of forensic science, health, and criminal justice. Moreover, the forensic nurse is trained to interact with those accused of crimes they did not commit. These areas require dialogue, as they are present in the settings of victims of crime, perpetrators, and their families; therefore, this connection allows effective contribution with specialists in forensic medicine and the police ${ }^{(20)}$.

Nurses can also work in health education areas, sharing and making the population aware of the different types of violence/abuses, besides detailing how, when, and which services should be accessed. When dealing with cases of violence, after identifying the nursing diagnoses, they shall be able to develop planning for nursing interventions ${ }^{(10)}$.

In post-violence care, the nurse shall provide safety to the victims; offer empathic care with physical and emotional support, both to victims and family members; carry out the collection of exams that can help clarify the investigation (documenting clues and evidence); carry out compulsory notification of different types of violence; and communicate situations of violence to the competent authorities ${ }^{(1)}$.

Forensic nurses can play a vital role in humanitarian forensic action. Humanitarian forensic action is the branch of science that involves forensic science for humanitarian purposes. It can be used to identify victims of mass disasters, or identify people who disappeared after a war, or even identify victims of epidemics ${ }^{(21)}$.

This role is related to the correct filling out of documentation, communication skills with the work team, and support to the families of the population served. This function can be highlighted in times of disaster, either of human or natural origin, such as wars, floods, major accidents, and epidemics, such as Ebola and in the current pandemic of the new Coronavirus ${ }^{(21)}$.

It should be noted that in the current COVID-19 pandemic, the role of the forensic nurse is of fundamental importance, both in direct care of the victims, as in the collection of material, and in the prevention of cross-contamination of patients and the healthcare team. Communication in the current context can present barriers, since everyone is protected with masks, glasses, face shields, gowns, caps, which can hinder personal relationship with the victims. Furthermore, in such situations, these people do not have the company of family or friends, due to the moment of the pandemic that recommends social isolation, making the assistance of these professionals essential ${ }^{(21)}$.

This is the right time to plan forensic nursing practice for the post-COVID-19 scenario. It is essential that the learning left by the pandemic is applied in the daily work of nurses, in precaution and care not only for the patient, but also for their own physical and mental integrity.

\section{FINAL CONSIDERATIONS}

The trajectory of forensic nursing has shown its contribution in criminal and civil areas and point to the emerging need for implementation and recognition of this practice within the scope of forensic investigations in Brazil. Although studies on this perspective are incipient, 
the literature has shown several possibilities of action with scientific and humanistic bases, essential to contribute to the elucidation of crimes, support and care for victims and aggressors, as well as for family members.

In the civil area, the role of nurses becomes relevant considering that they can contribute to the performance of audits and consultancy on nursing issues. Given this reality, a new field of studies to be explored by nurses in the forensic area is observed. It is noted that the inclusion of the content "forensic nursing" in the curricula of undergraduate nursing courses is required, aiming to better prepare these professionals for this new area.

\section{RESUMO}

Teorizar e refletir sobre as possibilidades de atuação do enfermeiro forense, enfatizando a atuação como perito civil e criminal, pautandose na legislação brasileira, nos princípios éticos e na integralidade do cuidado ao ser humano. É um estudo teórico com características reflexivas e críticas de natureza exploratória. Foi pautado na história do desenvolvimento da especialidade de enfermagem forense no âmbito internacional e nacional. Está organizado em quatro categorias, a saber: áreas de atuação do enfermeiro forense em países norteamericanos; estado da arte da enfermagem forense norte americana e a realidade brasileira e atuação do profissional enfermeiro diante da violência. Dessa forma, concatenaram-se a história internacional, panorama nacional e aprofundamento teórico. As evidências da contribuição da enfermagem forense nas áreas criminais e cíveis apontam a necessidade emergente de implementação e reconhecimento dessa prática no âmbito das perícias forenses no Brasil com a inclusão do tema nos cursos de graduação.

\section{DESCRITORES}

Enfermagem Forense; Prova Pericial; Exposição à Violência; Prática Avançada de Enfermagem; Sistema de Justiça.

\section{RESUMEM}

Teorizar y reflexionar sobre las posibilidades de actuación del enfermero forense, con énfasis en su actuación como perito civil y criminal, pautándose en la legislación brasileña, en los principios éticos y en la integralidad del cuidado al ser humano. Es un estudio teórico con características reflexivas y críticas de carácter exploratorio. Se pautó en la historia del desarrollo de la especialidad enfermería forense en el ámbito internacional y nacional. Está organizado en cuatro clases: Áreas de actuación del enfermero forense en países norteamericanos; estado del arte de la enfermería forense norte americana y la realidad brasileña y la actuación del profesional enfermero frente a la violencia. De esta forma se pudo unir la historia internacional, el panorama nacional y el perfeccionamiento teórico. Las evidencias de la contribución de la enfermería forense en las áreas criminales y civiles destacan la necesidad emergente de implementación y reconocimiento de esta práctica en el ámbito de las pericias forenses en Brasil con la inclusión del tema en los cursos de graduación.

\section{DESCRIPTORES}

Enfermería Forense; Testimonio de Experto; Exposición a la Violencia; Enfermería de Práctica Avanzada; Sistema de Justicia.

\section{REFERENCES}

1. Morse J. Legal mobilization in medicine: Nurses, rape kits, and the emergence of forensic nursing in the United States since the 1970s. Social Science \& Medicine. 2019;222:323-34. DOI: https://doi.org/10.1016/j.socscimed.2018.12.032.

2. Ahn HK, Sung MH. The Influences of Role Awareness, Experience and Competency on Performance of Forensic Nursing Role among Emergency Department Nurses. Journal of East-West nursing research. 2018;31;24(1):10-9. DOI: https://doi.org/10.14370/ JEWNR.2018.24.1.10.

3. Harper-Leatherman AS, Huang L. Introduction to Teaching Chemistry with Forensic Science. In: Harper-Leatherman AS, Huang L, editors. Teaching Chemistry with Forensic Science American Chemical Society. 2a ed. Washington: ACS Publication; 2019. p. 1-11.7.

4. Drake SA, Koetting C, Thimsen K, Downing N, Porta C, Hardy P, et al. Forensic Nursing State of the Science: Research and Practice Opportunities. J Forensic Nurs. 2018;14(1):3-10. DOI: https://doi.org/10.1097/JFN.0000000000000181.

5. Gomes CIA. Preservação dos vestígios forenses: conhecimentos e práticas dos Enfermeiros do Serviço de Urgência e/ou Emergência [Dissertation]. Coimbra: Universidade de Coimbra; 2016.

6. Lynch VA. Clinical forensic nursing: a new perspective in the management of crime victims from trauma to trial. Crit Care Nurs Clin North Am. 1995;7(3):489-507. DOI: https://doi.org/10.1016/S0899-5885(18)30377-0.

7. Ferreira CME. Conhecimento dos enfermeiros sobre práticas forenses no intra-hospitalar [Dissertation]. Viseu: Instituto Politécnico de Viseu; 2018.

8. Johnson J, Sievers V. The Role of the Forensic Nurse Expert. Evidence Technology Magazine [Internet]. 2019 [cited 13 Nov 2020];17(3). Available from: https://read.nxtbook.com/wordsmith/evidence_technology/fall_2019/the_role_of_the_forensic_nurs.html.

9. Maguire K, Raso M. Reflections on Forensic Nursing: An Interview with Virginia A. Lynch. J Forensic Nurs. 2017;13(4):210-15. DOI: https://doi.org/10.1097/JFN.0000000000000174.

10. Silva KB, Silva RC. Enfermagem Forense: uma especialidade a conhecer. Cogitare enfermagem. 2009;14(3):564-8. DOI: http://dx.doi. org/10.5380/ce.v14i3.16191.

11. Brasil. Conselho Federal de Enfermagem. Resolução n. 556, de 23 de agosto de 2017. Regulamenta a atividade do Enfermeiro Forense no Brasil, e dá outras providências [Internet]. Brasil: COFEN; 2017 [cited 27 June 2020]. Available from: http://www.cofen.gov.br/resolucaocofen-no-05562017_54582.html.

12. Brasil. Lei № 12030 de 17 de setembro de 2009. Dispõe sobre as perícias oficiais e dá outras providências [Internet]. Diário Oficial da União, Brasília, 18 Set 2009 [cited 27 Jun 2020]. Seção 1, p. 1. Available from: https://www.planalto.gov.br/ccivil_03/_ato20072010/2009/lei/l12030.htm.

13. Brasil. Decreto-Lei № 3.689 de 03 de outubro de 1941. Código de Processo Penal [Internet]. Diário Oficial da União, Brasília, 13 Out 1941 [cited 27 June 2020]. Seção 1, p. 19699. Available from: https://www.planalto.gov.br/ccivil_03/decreto-lei/del3689.htm. 
14. dos Santos AA, Silva JF, Ferreira MB, Souza Conceição VL, Cunha Alves DM. Estado da arte da Enfermagem Forense no cenário atual da saúde. Revista Eletrônica Acervo Saúde. 2019;(27):e1015. DOI: https://doi.org/10.25248/reas.e1015.2019P.

15. Tavares DN. Enfermagem Forense: um estudo sobre a realidade da nova especialidade no Brasil a partir da experiência estadunidense [Monografia]. Niterói: Universidade Federal Fluminense; 2013 [cited 13 Apr. 2021]. Available from: https://app.uff.br/riuff/ bitstream/1/5131/1/TCC\%20Daniel\%20do\%20Nascimento\%20Tavares.pdf.

16. Brasil. Secretaria de Estado da Segurança Pública e Administração Penitenciária - SESP/PR. Edital de concurso público nº 01/107 [Internet]. 2017 [cited 27 Jun 2020]. Available from: https://fs.ibfc.org.br/arquivos/99b2aea1f96b37b3f119536d542f9712.pdf.

17. Silva ESC. A atuação profissional na perícia. [Internet]. Brasil: Âmbito Jurídico; 2018 [cited 13 Nov 2020]. Available from: https:// ambitojuridico.com.br/cadernos/direito-processual-civil/a-atuacao-profissional-na-pericia/.

18. Davis AB, Gaudino JA, Soskolne CL, Al-delaimy WK. The role of epidemiology in firearm violence prevention: a policy brief. Int J Epidemiol. 2018;47(4):1015-9. DOI: https://doi.org/10.1093/ije/dyy059.

19. Brasil. Decreto № 94.406, de 8 de junho de 1987. Regulamenta a Lei № 7.498, de 25 de junho de 1986, que dispõe sobre o exercício da Enfermagem, e dá outras providências [Internet]. Brasília; 1986 [cited 27 June 2020]. Available from: http://www.cofen.gov.br/ decreto-n-9440687_4173.html.

20. Gorea RK, Lynch VA. Forensic nursing - A boon to the society. J Punjab Acad Forensic Med Toxicol. 2003 [cited 13 Apr 2021];(3):32-6. Available from: https://www.indianjournals.com/ijor.aspx?target=ijor:jpafmat\&volume=2003\&issue=3\&article=009.

21. Gorea RK. Forensic Nursing in Humanitarian Forensics. International Journal of Ethics, Trauma \& Victimology [Internet]. 2020 [cited 14 Apr 2021];6(02):1-5. Available from: https://www.forensicwayout.org/journals/index.php/IJETV/article/view/1086. 